\title{
A thyroid nodule revealing a paraganglioma in a patient with a new germline mutation in the succinate dehydrogenase $B$ gene
}

\author{
Baha Zantour, Brigitte Guilhaume, Frédérique Tissier ${ }^{1}$, Albert Louvel ${ }^{1}$, Xavier Jeunemaitre ${ }^{2}$, \\ Anne-Paule Gimenez-Roqueplo ${ }^{2}$ and Xavier Bertagna \\ Service des Maladies Endocriniennes et Métaboliques, ${ }^{1}$ Anatomo-Pathologie, Hôpital Cochin, ${ }^{2}$ Département de Génétique, Hôpital Européen Georges \\ Pompidou, Assistance Publique/Hôpitaux de Paris, Paris, France and the COMETE and PGL.NET networks
}

(Correspondence should be addressed to X Bertagna, Endocrinology, Pavillon Cornil, Hôpital Cochin, 27, rue du Faubourg St Jacques, 75014 Paris, France; Email: xavier.bertagna@cch.ap-hop-paris.fr)

\begin{abstract}
A 32-year-old asymptomatic female was diagnosed with an isolated thyroid nodule of $2.5 \mathrm{~cm}$ diameter. Fine needle aspiration suggested a medullary thyroid carcinoma. Consequently, a total thyroidectomy was performed. The nodule stained positive for chromogranin A, neurone-specific enolase and synaptophysin, but not for calcitonin. Finally, pathological analysis showed a thyroid paraganglioma. Although the tumour appeared to be sporadic in a patient with no personal or familial history of paraganglioma and/or pheochromocytoma, we have identified a new mutation (392delC) of the succinate dehydrogenase-B $(S D H B)$ gene in the genomic DNA extracted from the leukocytes of the patient. That mutation induced a shift in the reading frame of the gene creating a premature stop codon (P131fsX135) which was predicted to result in a truncated SDHB protein of 135 amino acids.

This report highlights the difficulties of this unexpected diagnosis of hereditary thyroid paraganglioma. It also discusses the clinical involvements in terms of familial screening and the necessary follow-up of the patient.
\end{abstract}

European Journal of Endocrinology $151433-438$

\section{Introduction}

Paragangliomas are usually benign tumours of the autonomous nervous system that are composed of cells derived from the primitive neural crest (1). They can be found in different locations from the middle ear and the skull base to the pelvic floor. In the head and the neck area, paragangliomas are located in close association with the parasympathetic nervous system along the cranial nerves and the arterial vasculature, but they may also be found in unusual sites such as the orbit, the paranasal sinuses or the thyroid (1-3). Thyroid paragangliomas are thought to arise from the inferior laryngeal paraganglia (2) which are sometimes situated within the thyroid capsule. They are extremely rare tumours which can be misinterpreted as medullary thyroid carcinomas (MTCs) and/or other primary or metastatic thyroid neoplasms (4). The symptoms are pulsatile tinnitus, hearing loss, deafness for head locations and pain or pulsating mass for the neck paragangliomas. In the thoracic and abdominal locations, paragangliomas can also secrete catecholamines (adrenal pheochromocytomas or extra-adrenal functional paragangliomas) and lead to high blood pressure, palpitations or sweating. The only curative therapy is early surgery which can be completed or replaced by radiation treatment if the tumour has extended to the blood vessels, cranial nerves or skull base. Paragangliomas are inherited in around $30 \%$ of cases. Usually, hereditary paragangliomas are multiple, recurrent and sometimes malignant. Three genes, the succinate dehydrogenase- $B,-C$ and $-D$ (SDHB, SDHC and SDHD), which encode three protein subunits of the cytochrome b of complex II in the mitochondrial respiratory chain, have been implicated in the genetics of hereditary paragangliomas (5-7). Germline mutations of SDHD gene are mostly found in patients with head and neck hereditary paragangliomas (8), whereas SDHB germline mutations have also been identified in patients with familial paragangliomas $(5,8)$, familial pheochromocytomas (5) and apparently sporadic paragangliomas (8) and/or pheochromocytomas (5). Only two mutations have been reported in the SDHC gene in a family with hereditary paragangliomas as well as in one case of apparently sporadic pheochromocytoma $(6,8,9)$. Herein, we report a case of a thyroid paraganglioma appearing as a classic solitary thyroid nodule which was first misdiagnosed as an MTC and in which we have found a new germline mutation of the SDHB gene. 


\section{Patient and methods}

\section{Patient}

The patient was a 32-year-old female who had an asymptomatic, single thyroid mass of about $2.5 \mathrm{~cm}$ diameter. Routine laboratory data showed normal plasma thyrotrophin $(1.29 \mathrm{mIU} / \mathrm{l})$, as well as undetectable plasma calcitonin $(<5 \mathrm{ng} / \mathrm{l})$. Anti-peroxidase and anti-thyroglobulin antibodies were negative in her blood. The patient's family history revealed only Hodgkin's disease in her dead father. Her personal medical history was negative for hypertension, thyroid or other endocrine disorders, neck irradiation, respiratory diseases, cyanotic heart diseases and other causes of chronic hypoxia. Ultrasound examination showed a $2.5 \mathrm{~cm}$ hypervascularized solid nodule of the upper pole of the left thyroid lobe. Fine needle aspiration of the nodule was performed and an MTC was then suspected. The patient underwent total thyroidectomy with resection of the cricoid cartilage and bilateral node dissection. The pathologist's description first suggested an MTC with amyloid stroma and unexpected immunohistochemical staining. Surprisingly, the tumour cells were strongly positive for synaptophysin, neurone-specific enolase, serotonin and chromogranin A, but they were negative for calcitonin. Further pathological evaluation diagnosed a thyroid paraganglioma. The results were negative in the search for other paraganglioma locations by octreotide scintigraphy and for catecholamine secretion by measurement of urinary metanephrines. Six years after the surgical operation, the patient is still alive. In addition, she feels well under substitutive treatment with L-thyroxine and without any evidence of recurrent disease.

\section{Methods}

Three haematoxylin and eosin-stained (HES) blocks of tissue were sent by the pathologist for review. Immunohistochemical stains were performed against the following antigens: thyroglobulin, calcitonin, chromogranin A, neurone-specific enolase, synaptophysin, serotonin, S-100 protein and carcinoembryonic antigen. Written informed consent was obtained for the DNA analysis. Peripheral DNA was obtained from a venous blood sample. Four exons of the SDHD gene, eight exons of the SDHB gene and six exons of the SDHC gene were amplified and directly sequenced as previously described (10).

\section{Results}

\section{Pathological findings (Fig. 1a and b)}

The tumour was mainly composed of large polyhedric cells and sometimes fusiform with poorly eosinophilic

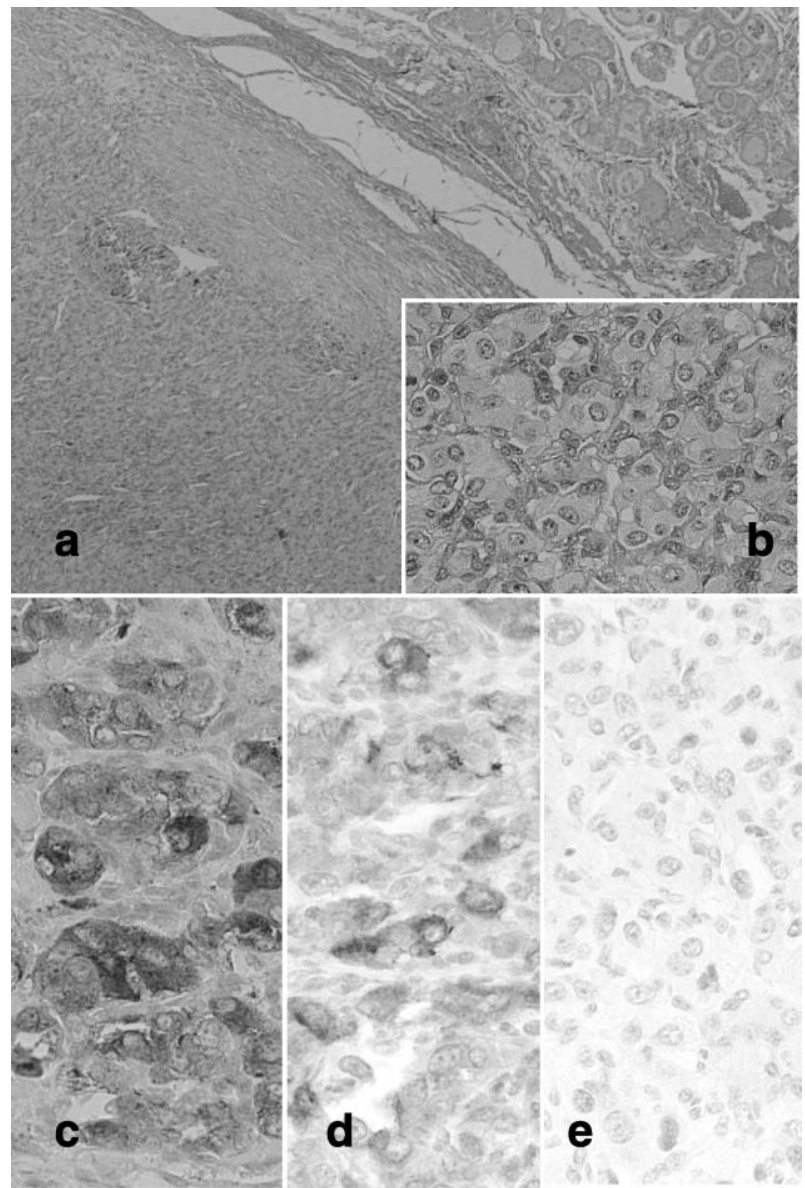

Figure 1 Paraganglioma: histological ((a) HES $\times 25$ and (b) HES $\times 200)$ and immunohistochemical staining with anti-synaptophysin $((c) \times 200)$, antichromogranin $A((d) \times 200)$ and anti-thyrocalcitonin $((e) \times 200)$ antibodies.

cytoplasm. Some nuclei were hyperchromatic or with irregular outlines. Cells were disposed in nests or sometimes in trabeculae separated by a thin conjunctivovascular area. The proliferation was obviously endocrinoid, the trabeculae were separated by capillaries with well-recognized endothelium. In many areas, cells were round with a clear finely granular cytoplasm. Within the periphery, there were small-sized cells with elongated nuclei (sustentacular cells). The proliferation was lobulated by fibro-vascular trabeculae, surrounded by a fibrous condensation which contained vessels with a thick wall. It also separated the tumour from the cellulo-adipose tissue and the normal adjacent thyroid tissue. Fibrous condensation was infiltrated in some areas and mitoses were found in the tumour.

\section{Immunohistochemical findings (Fig. 1c, d and $e$ )}

The tumour was strongly and entirely positive for neurone-specific enolase, chromogranin A, synaptophysin and locally positive for serotonin. The sustentacular 
cells were positive for the S-100 protein. The tumour was negative for thyroglobulin, calcitonin and carcinoembryonic antigen.

\section{Mutation analysis (Fig. 2)}

We found no mutation in the SDHD and the SDHC genes but we identified a heterozygous germline mutation in exon 4 of the SDHB gene. Direct sequencing showed the deletion of cytosine at the 392 nucleotide position (392delC). That mutation led to a shift in the reading frame of the gene creating a premature stop codon (P131fsX135) which was predicted to result in a truncated SDHB protein of 135 amino acids.

\section{Discussion}

Intrathyroidal paragangliomas are rare tumours affecting women between 40 and 50 years of age. Most of the time they appear as an asymptomatic thyroid nodule (4). The diagnosis of intrathyroidal paraganglioma may be extremely difficult on a purely morphological basis, and immunohistochemistry is essential to show the difference from other types of tumours (11). Those tumours are essentially MTC, Hurthle cell neoplasm, metastatic renal cell carcinoma, hyalinizing trabecular adenoma, atypical follicular adenoma and metastatic carcinoid tumours of the thyroid (4). In the present case, the presence of nests of large polygonal cells separated by variable amounts of amyloid and richly vascularized fibrous stroma as well as the presence of mitoses and nuclear abnormalities first led to the diagnosis of MTC. However, the lack of staining for calcitonin and for carcinoembryonic antigen as well as the identification of S-100 protein-positive sustentacular cells later excluded the diagnosis of MTC. Calcitonin immunostaining is always present in MTC, and its intensity is used as a prognosis marker: poorly stained tumours are less differentiated and more agressive (12). However, diagnosis may be very difficult. Hence, a battery of epithelial, neural and hormonal immunohistochemical markers are mandatory in the differential diagnosis between paraganglioma and MTC (4).

At least four genetic loci have been implied in the pathogenesis of hereditary paragangliomas. Three genes of the loci, paraganglioma1 (PGL1) on chromosome 11q23 (13), PGL3 on chromosome 1q21 (14) and PGL4 on chromosome 1p36 (5) have been identified. They encoded for the mitochondrial complex II (succinate dehydrogenase, succinate:ubiquinone oxidoreductase) subunits SDHD (7), SDHC (6) and SDHB (5) respectively. The PGL2 gene located at the $11 \mathrm{q} 13$ chromosome position (15) still has to be confirmed and identified. The succinate dehydrogenase participates in the electron transport chain and in the Krebs tricarboxylic acid cycle in the mitochondria (16-19). It is formed by two catalytic subunits (SDHA and SDHB) which are anchored to the membrane by two hydrophobic integral membrane proteins (SDHC and SDHD). It was previously demonstrated that inactivation of $S D H D$ or $S D H B$ genes induced complete loss of succinate dehydrogenase activity and activation of the angiogenic pathway $(10,20)$. Several mechanisms such as oxygen sensing and/or the apoptosis hypothesis (21) are currently being discussed to explain the tumorigenesis triggered by the loss of succinate dehydrogenase activity. The SDHD mutations are usually reported in hereditary paragangliomas located in the head and neck (most often developed in the carotid glomus). They are also found in familial and/or apparently

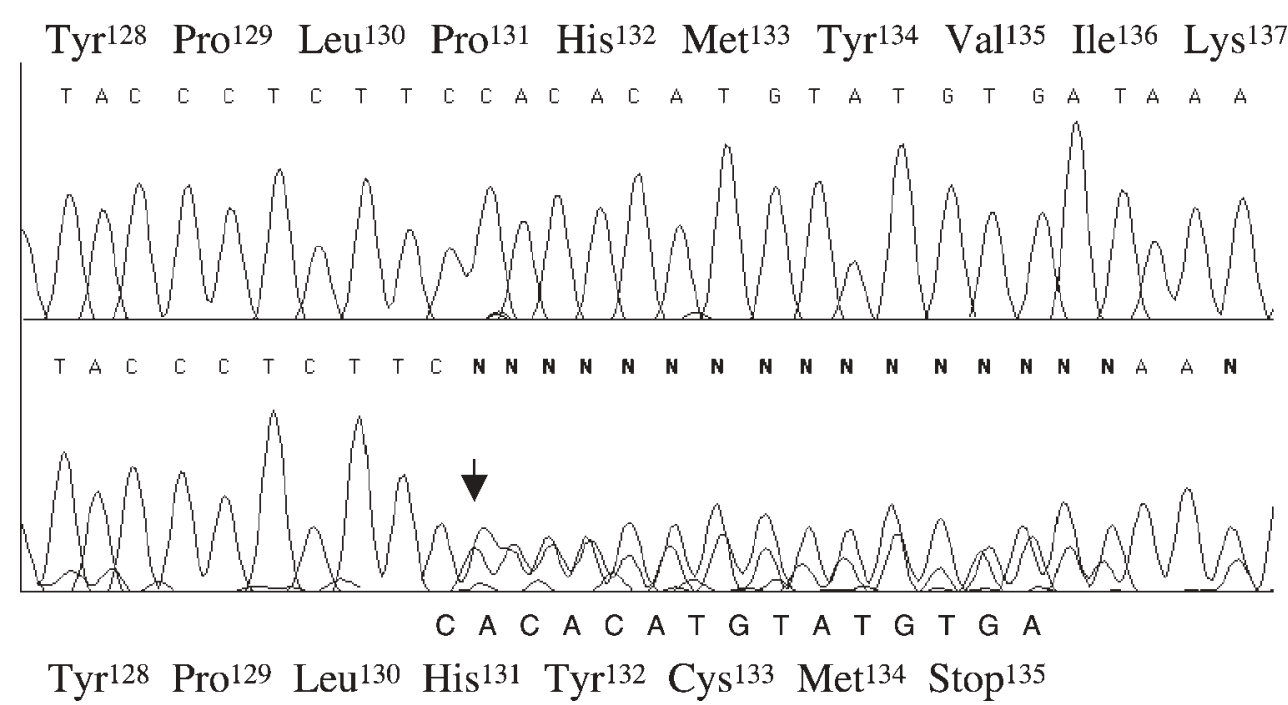

Figure 2 Electrophoretogram corresponding to a control normal SDHB sequence (upper electrophoretogram) and to the patient sequence (lower electrophoretogram) showing the deletion of cytosine 392 and the introduction of a stop codon (TGA) at amino acid position 135. 
sporadic pheochromocytomas $(7,18,22,23)$. The SDHB mutations are preferentially observed in familial and apparently sporadic pheochromocytomas. Table 1 shows the mutations reported in the SDHB gene. In the present patient we found a heterozygous deletion of cytosine at nucleotide 392 in exon 4 of the SDHB gene resulting in a false-sense codon (proline changed to histidine) in the 131 amino acid position, and in a termination codon at 135. This cytosine was previously reported to be changed in guanine inducing a missense mutation (P131R) in the SDHB gene in one Polish family with head and neck hereditary paragangliomas (23). Familial paragangliomas caused by SDHD mutations demonstrate maternal genomic imprinting effects and the disease phenotype is manifested only after paternal transmission (24). The phenotypic expression of $S D H B$ and SDHC mutations do not reveal parent-of-origin effects which would be clinical evidence for genetic imprinting of these genes (5, 6). Other differences between SDHD and SDHB mutations have been noted. There is no evidence for a founder effect in the different mutations of SDHB (8), contrasting with SDHD gene mutations which show a founder effect in Dutch families (25). The SDHD gene is included within the region of loss of heterozygosity exclusively targeting the maternal allele on chromosome 11q22-23 which has been observed at distant flanking markers in paragangliomas (20, 22, 24-27). Gimenez-Roqueplo et al. (28) have recently shown that germline mutations of the SDHB gene associated with a loss of heterozygosity at the $1 \mathrm{p} 36$ chromosome were strongly associated with extra-adrenal pheochromocytomas and conferred a high risk of recurrence or malignancy. Although our patient's paraganglioma was apparently sporadic, the presence of a germline mutation in her genome demonstrated an inherited disease (29-34). Her parents could not be studied but there was no clinical evidence of the disease, suggesting a de novo mutation. Whether our patient is the cas simplex remains hypothetical. In any case, there are two important reasons for involvement. On a familial basis, a presymptomatic genetic testing should be proposed for her first-degree related parents and all individuals determined to be at risk of the familial disease should be engaged in regular follow-ups for the possibility of paragangliomas and/or pheochromocytomas. On a clinical basis, this patient has a high risk of recurrence and should be regularly screened.

Finally, attention should be drawn to apparent MTCs which do not show calcitonin expression. The diagnosis of paraganglioma with an unusual location in the head and neck should lead to the analysis of the SDHB gene.

Table 1 Principal causal mutations of the SDHB gene.

\begin{tabular}{|c|c|c|c|c|}
\hline Exon & Nucleotide change* & Amino acid change** & Clinical features ${ }^{\star \star \star}$ & Reference \\
\hline 2 & $79 \mathrm{C}>\mathrm{T}$ & $\mathrm{R} 27 \mathrm{X}$ & S-Pheo & 29 \\
\hline 2 & 86-87insCAG & A29-Q30 insQ & S-Pheo & 29 \\
\hline 2 & 88delC & Altered reading frame & F-Pheo & 30 \\
\hline 2 & $127 G>C$ & A43P & S-Pheo & 28 \\
\hline 2 & $136 C>G$ & R46G & S-Pheo & 29 \\
\hline 2 & $136 \mathrm{C}>\mathrm{T}$ & R46X & S-Pheo & 30 \\
\hline 2 & $137 G>A$ & $\mathrm{R} 46 \mathrm{Q}$ & S-Pheo & 10 \\
\hline 2 & 174-175GC $>$ TT & Q59X & S-PGL & 23 \\
\hline IVS2 & $+3 G>C$ & Altered splicing site & S-Pheo & 30 \\
\hline 3 & 207insC & Altered reading frame & F-PGL & 23 \\
\hline 3 & $268 \mathrm{C}>\mathrm{T}$ & R90X & F-Pheo & 5 \\
\hline 4 & $302 G>A$ & C101Y & S-Pheo & 29 \\
\hline 4 & $380 \mathrm{~T}>\mathrm{A}$ & $1127 \mathrm{~N}$ & S-Pheo & 31 \\
\hline 4 & $392 C>G$ & P131R & F-PGL & 23 \\
\hline 4 & 392delC & P131fsX135 & S-PGL & This report \\
\hline 4 & $395 A>C$ & $\mathrm{H} 132 \mathrm{P}$ & F-Pheo & 32 \\
\hline IVS4 & $-1 G>A$ & Altered splicing site & F-PGL & 30 \\
\hline IVS4 & $+1 G>A$ & Altered splicing site & S-PGL & 33 \\
\hline 6 & $574 \mathrm{~T}>\mathrm{C}$ & C192R & S-Pheo & 29 \\
\hline 6 & 583-585delAGC & $\Delta \mathrm{S} 195$ & S-Pheo & 34 \\
\hline 6 & $587 G>A$ & C196Y & S-Pheo & 29 \\
\hline 6 & $590 C>G$ & P197R & F-Pheo & 5 \\
\hline 6 & 591delC & Altered reading frame & S-Pheo & 5 \\
\hline 6 & 620-621delTG & Altered reading frame & S-Pheo & 28 \\
\hline 6 & 660-661ins T & D221X & S-Pheo & 31 \\
\hline 6 & $688 \mathrm{C}>\mathrm{T}$ & $\mathrm{R} 230 \mathrm{C}$ & S-Pheo & 28 \\
\hline 7 & 713-716delTCTC & Altered reading frame & S-Pheo & 29 \\
\hline 7 & $725 G>A$ & $\mathrm{R} 242 \mathrm{H}$ & S-Pheo & 29 \\
\hline 7 & $747 C>A$ & C249X & S-Pheo & 29 \\
\hline
\end{tabular}

*Nucleotide number on the cDNA sequence; **amino acid number; $* \star * F-P G L$, familial paraganglioma. S-Pheo, apparently sporadic functional paraganglioma (catecholamine-secreting paraganglioma or pheochromocytoma); F-Pheo, familial pheochromocytoma; S-PGL, apparently sporadic paraganglioma. 


\section{Acknowledgements}

This study was supported by Groupement d'Interét Scientifique-Institut des Maladies Rares and the Cortico Medullo Tumeurs Endocrines network. A-P G-R holds a Contrat Individuel d'Objectif from INSERM.

\section{References}

1 Zak FG \& Lawson W. The paraganglionic chemoreceptor system. In Physiology, Pathology and Clinical Medicine, pp 157. New York: Springer Verlag, 1983.

2 Brownlee RE \& Shockley WW. Thyroid paraganglioma. Annals of Otology, Rhinology, and Laryngology 1992101 293-299.

3 Farhi F, Dikman JH, Lawson W, Cabin RH \& Zak FG. Paragangliomatosis associated with mutiple endocrine adenomas. Archives of Pathology and Laboratory Medicine $1976 \mathbf{1 0 0} 495-498$.

4 Laguette J, Matias-Guiu X \& Rosai J. Thyroid paraganglioma: a clinicopathologic and immunohistochemical study of three cases. American Journal of Surgical Pathology 199721 748-753.

5 Astuti D, Latif F, Dallol A, Dahia PL, Douglas F, George E, Skoldberg F, Husebye ES, Eng C \& Maher ER. Gene mutations in the succinate dehydrogenase subunit SDHB cause susceptibility to familial pheochromocytoma and to familial paraganglioma. American Journal of Human Genetics 200169 49-54.

6 Niemann S \& Muller U. Mutations in SDHC cause autosomal dominant paraganglioma, type 3. Nature Genetics 200026 268-270.

7 Baysal BE, Ferrell RE, Wilett-Brozick JE, Lawrence EC, Myssiorek D, Bosch A, Vander Mey A, Taschner PE, Rubinstein WS, Meyers EN, Richard CW III, Cornelisse CJ, Devilee P \& Devlin B. Mutations in SDHD, a mitochrondrial complex II gene, in hereditary paraganglioma. Science 2000 287 848-851.

8 Baysal BE, Willett-Brozick JE, Lawrence EC, Drovdlic CM, Savul SA, McLeod DR, Yee HA, Brackmann DE, Slattery WH III, Myers EN, Ferrell RE \& Rubinstein WS. Prevalence of SDHB, SDHC and SDHD germline mutations in clinic patients with head and neck paraganliomas. Journal of Medical Genetics 2002 $39178-183$.

9 Niemann S, Muller U, Engelhardt D \& Lohse P. Autosomal dominant malignant and catecholamine-producing paraganglioma caused by a splice donor site mutation in SDHC. Human Genetics $200311392-94$.

10 Gimenez-Roqueplo AP, Favier J, Rustin P, Rieubland C, Kerlan V, Plouin PF, Rotig A \& Jeunemaitre X. Functional consequence of a SDHB mutation in an apparently sporadic pheochromocytoma. Journal of Clinical Endocrinology and Metabolism $2002 \mathbf{8 7}$ $4771-4774$.

11 Korat O, Trojanowski JQ, Livolsi VA \& Merino MJ. Antigen expression in normal paraganglia and paragangliomas. Surgical Pathology $1988133-40$.

12 Saad FA, Ordonez NG, Guido JJ \& Samaan NG. The prognostic value of calcitonin immunostaining in medullary carcinoma of the thyroid. Journal of Clinical Endocrinology and Metabolism $198459850-856$.

13 Heutink P, van der Mey AG, Sandkuijl LA, van Gils AP, Bardoel A, Breedveld GJ, vanVliet M, van Ommen GJ, Cornelisse CJ, Oostra BA, Weber JL \& Devilee A. A gene subject to genomic imprinting and responsible for hereditary paragangliomas maps to chromosome 11q23-q ter. Human Molecular Genetics 19921 7-10.

14 Niemann S, Becker-Follmann J, Nurnberg G, Ruschendorf F, Sieweke N, Hugens-Penzel M, Traupe H, Wienker TF, Reis A \& Muller A. Assignment of PGL3 to chromosome 1 (q21-q23) in a family with autosomal dominant non-chromaffin paraganglioma. American Journal of Medical Genetics 200198 32-36.

15 Mariman ECM, van Beersum SEC, Cremers CWRJ, van Baars FM \& Ropers HH. Analysis of a second family with hereditary nonchromaffin paragangliomas locates the underlying gene at the proximal region of chromosome 11q. Human Genetics 199391 357-361.

16 Hagerhall C. Succinate: quinone oxidoreductase. Variations on a conserved theme. Biochimica et Biophysica Acta $1997 \mathbf{1 3 2 0}$ 107-141.

17 Bougeron T, Rustin P, Chretien D, Birch-Machin M, Bourgeois M, Viegas-Pequignot E, Munnich A \& Rotig A. Mutation of a nuclear succinate deshydrogenase gene results in mitochondrial respiratory chain deficiency. Nature Genetics 199511 144-149.

18 Gimm O, Armanios M, Dziema H, Neumann HP \& Eng C. Somatic and occult germ-line mutations in SDHD, a mitochondrial complexe II gene in non familial pheochromocytoma. Cancer Research $2000606822-6825$.

19 Cavalli LR \& Liang BC. Mutagenesis, tumorigenicity and apoptosis: are the mitochondria involved? Mutation Research 1998398 $19-26$.

20 Gimenez-Roqueplo AP, Favier J, Rustin P, Mourad JJ, Plouin PF, Corvol P, Rotig A \& Jeunemaitre X. The R22X mutation of the SDHD gene in hereditary paraganglioma absolishes the enzymatic activity of complex II in the mitochondrial respiratory chain and activates the hypoxia pathway. American Journal of Human Genetics $2001691186-1197$.

21 Eng C, Kiuru M, Fernandez MJ \& Aaltonen LA. A role for mitochondrial enzymes in inherited neoplasia and beyond. Nature Reviews Cancer 20033 193-202.

22 Astuti D, Douglas F, Lennard TW, Aligianis IA, Woodward ER, Evans DG, Eng C, Latif F \& Maher ER. Germline SDHD mutations in familial phaeochromocytoma. Lancet 2001357 1181-1182.

23 Baysal BE, Willet-Brozick JE, Lawrence EC, Drovdlic CM, Savul SA, McLeod DR, Yee HA, Brackmann DE, Slattery WH, Myers EN, Ferrell RE \& Rubinstein WS. Prevalence of SDHB, SDHC, and SDHD germ like mutations in clinic patients with head and neck paragangliomas. Journal of Medical Genetics 200239 178-183.

24 Vander Mey AG, Maaswinkel-Mooy PD, Cornelisse CJ, Schmidt PH \& van de Kamp JJ. Genomic imprinting in hereditary glomus tumours: evidence for new genetic theory. Lancet 1989 ii 1291-1294.

25 Taschner PE, Jansen JC, Baysal BE, Bosch A, Rosenberg EH, Brocker-Vriends AH, vander Mey AG, Van Ommen GJ, Cornelisse CJ \& Devilee P. Nearly all hereditary paragangliomas in The Netherlands are caused by two founder mutations in the SDHD gene. Genes, Chromosomes and Cancer $200131274-281$.

26 Van Schothorst EM, Beekman M, Torremans P, Kuipers Dijkshoorn NJ, Wessels HW, Bardoel AF, van der Mey AG, van der Vijver MJ, van Ommen GJ, Devilee P \& Cornelisse C. Paragangliomas of the head and neck region show complete loss of heterozygosity at 11q22-q23 in chief cells and the flow-sorted DNA aneuploid fraction. Human Pathology 199829 1045-1049.

27 Hensen EF, Jordanova ES, van Minderhout IJ HM, Hogendoorn PCW, Taschner PEM, van der Mey AGL, Devilee P \& Cees J. Somatic loss of maternal 11 causes parent-of-origin-dependent inheritance in SDHD-linked paraganglioma and phaeochromocytoma families. Oncogene 200423 4076-4083.

28 Gimenez-Roqueplo A-P, Favier J, Rustin P, Rieublanc C, Crespin M, Nau V, Van Kien PK, Corvol P, Plouin PF, Jeunemaitre X \& the COMETE network. Mutations in the SDHB gene are associated with extra-adrenal and/or malignant phaechromocytomas. Cancer Research 200363 5615-5621.

29 Neumann H, Bausch B, McWhinney SR, Bender BU, Gimm O, Franke G, Schipper J, Klisch J, Altehofer C, Zerres K, Januszewicz A \& Eng C. Germline mutations in nonsyndromic pheochromocytomas. New England Journal of Medicine 2002346 1459-1466.

30 Benn DE, Groxson MS, Tucker K, Bambach CP, Richardson AL, Delbridge L, Pullan PT, Hammoud J, Marsh DJ \& Robinson BG. Novel succinate deshydrogenase subunit B (SDHB) mutation in familial phaeochromocytomas and paragangliomas, but an absence of somatic SDHB mutation in sporadic phaeochromocytomas. Oncogene 200322 1358-1364. 
31 Astuti D, Hart-Holden N, Latif F, Lalloo F, Black GC, Lim C, Moran A, Grossman AB, Hodgson SV, Freemont A, Ramsden R, Eng C, Evans GR \& Maher ER. Genetic analysis of mitochondrial complex II subunits SDHD, SDHB and SDHC in paraganglioma and phaeochromocytoma susceptibility. Clinical Endocrinology $2003 \mathbf{5 9}$ $728-733$.

32 Maier-Woelfle M, Brändle M, Komminoth P, Saremaslani P, Schmid S, Locher T, Heitz PU, Krull I, Galeazzi RL, Schmid C \& Perren A. A novel succinate dehydrogenase subunit B gene mutation, H132P, causes familial malignant sympathetic extraadrenal paragangliomas. Journal of Clinical Endocrinology and Metabolism 200489 362-367.

33 Douwes Dekker PB, Hogendoom PCW, Kuipers-Dijkshoom N, Prins FA, van Duinen SG, Taschner PEM, van der Mey AGL \&
Cornelisse CJ. SDHD mutations in head and neck paragangliomas result in destabilization of complex II in the mitochondrial respiratory chain with loss of enzymatic activity and abnormal mitochondrial morphology. Journal of Pathology $2003201480-486$.

34 Cascon A, Ruiz-Llorente S, Fraga MF, Leton R, Telleria D, Sastre J, Jose Diez J, Martinez Diaz-Guerra G, Diaz Perrez JA, Benitez J, Esteller M \& Robledo M. Genetic and epignetic profile of sporadic pheochromocytomas. Journal of Medical Genetics 200441 e30.

Received 14 June 2004

Accepted 20 July 2004 